\title{
GvHD Final Skin Score 1
}

National Cancer Institute

\section{Source}

National Cancer Institute. GvHD Final Skin Score 1. NCI Thesaurus. Code C131027.

Body surface area involvement is 1-18 percent. 